PONTIFÍCIA UNIVERSIDADE CATÓLICA DO RIO DE JANEIRO

\title{
Educação Financeira e Preparo para a Aposentadoria dos Jovens Universitários do Rio de Janeiro
}

\section{Daniel Giannini Silva Vasconcellos}

Trabalho de Conclusão de Curso

CENTRO DE CIÊNCIAS SOCIAIS - CCS

DePARTAMENTO de AdMINISTRAÇÃo

Graduação em Administração de Empresas 
Daniel Giannini

\section{Educação Financeira e Preparo para a Aposentadoria dos Jovens Universitários do Rio de Janeiro}

Trabalho de Conclusão de Curso

Trabalho de Conclusão de Curso, apresentado ao programa de graduação em Administração da PUC-Rio como requisito parcial para a obtenção do titulo de graduação em Administração.

Orientador(a): Liana Ribeiro

Rio de Janeiro Novembro de 2017 


\section{Agradecimentos}

Primeiramente agradeço a Deus por mais um fechamento desse ciclo e começo de uma nova etapa.

À minha prima Germana, um agradecimento especial por ter me dado a oportunidade de estar estudando nessa universidade maravilhosa que é a PUCRio. Por ter sempre me apoiado e acreditado no meu potencial.

Um agradecimento especial à minha mãe que sempre lutou por mim e sempre acreditou na minha capacidade, sempre me apoiando em todas as decisões que eu tomei durante a minha trajetória na PUC.

Aos meus professores Roberto Gil Uchoa e Andrea Cherman por me ajudarem no crescimento profissional, pelos conhecimentos adquiridos e por fazerem parte da minha nova maneira de pensar e ver a situações do dia-a-dia.

À Julia Faria, por toda a ajuda e apoio em momentos de dificuldade que passei por essa etapa na PUC.

Aos meus colegas de classe; especialmente, Ana Carolina Müller, João Paulo, Amanda Mograbi, João Victor Pestana e Nicolas Jaoude por compartilharem comigo os momentos de estudo que foram fundamentais para vencer algumas etapas ao longo dos anos de graduação.

À minha orientadora, Liana Ribeiro, por sua disposição para me auxiliar na elaboração de todas as etapas deste trabalho.

Finalmente, agradeço a todos os meus familiares e amigos próximos ou à distância, através de seus gestos e palavras, contribuíram com conselhos, apoio e entusiasmo para a realização dessa jornada. Estão todos no meu coração. 


\section{Resumo}

Giannini, Daniel. Educação Financeira e Preparo para a Aposentadoria dos Jovens Universitários do Rio de Janeiro. Rio de Janeiro, 2017. 43 p. Trabalho de Conclusão de Curso - Departamento de Administração. Pontifícia Universidade Católica do Rio de Janeiro.

Este trabalho visa entender o nível de conhecimento dos jovens universitários e saber se eles estão se preparando para a aposentadoria. Foi realizada uma pesquisa com jovens universitários do Rio de Janeiro que estudam ou que são recém-formados. Foi abordado o nível de educação financeira, a importância e preparo para a aposentadoria e o planejamento financeiro dos jovens. O estudo revelou que embora os jovens tenham conhecimento financeiro básico, possuem defasagem no que se refere a tipos de investimentos existentes. Foi percebido também que os jovens continuam despreparados e despreocupados com a aposentadoria e que eles não fazem um planejamento financeiro adequado para atingirem seus objetivos. O resultado desse estudo traz oportunidades para pesquisas mais aprofundadas sobre o tema e para mudanças necessárias para melhorar a alfabetização financeira dos jovens no Brasil.

\section{Palavras-chave}

Educação financeira; conhecimento financeiro; aposentadoria 


\section{Abstract}

Giannini, Daniel. Financial Literacy and Preparation for the Retirement of Young University Students of Rio de Janeiro.. Rio de Janeiro, 2017. 43 p. Final paper - Business Department. Pontifícia Universidade Católica do Rio de Janeiro.

This work aims to understand the level of knowledge of young college students and to know if they are preparing for retirement. A survey was carried out with young university students from Rio de Janeiro studying or who are newly graduated. It addressed the level of financial education, the importance and preparation for the retirement and financial planning of young people. The study found that while young people have basic financial knowledge, they are lagging behind in terms of existing types of investments. It was also noticed that young people remain unprepared and unconcerned about retirement and that they do not make adequate financial planning to achieve their goals. The result of this study provides opportunities for further research on the subject and for the changes needed to improve the financial literacy of young people in Brazil.

\section{Key-words}

Financial Literacy; financial knowledge; retirement 


\section{Sumário}

1.Introdução ao tema e ao problema do estudo 1

1.1. Objetivo do estudo 2

1.2. Objetivos intermediários do estudo 2

1.3. Delimitação do estudo 3

1.4. Justificativa e relevância do estudo 3

2 Revisão de literatura $\quad 4$

2.1. Educação Financeira no Brasil 4

2.2. Comportamento Financeiro 5

2.3. Planejamento Financeiro 6

2.4. Importância de poupar e investir 8

2.5. Tipos de Investimento 9

2.5.1 PGBL e VGBL 11

3 Métodos e procedimentos de coleta e de análise de dados do estudo 14

3.1. Tipo de pesquisa realizada 14

3.2. Fontes de informação selecionadas para coleta de dados no estudo14

3.3. Procedimentos e instrumentos de coleta de dados utilizados no estudo 15

3.4. Formas de tratamento e análise dos dados coletados para o estudo16 $\begin{array}{ll}\text { 3.5. Limitações do Método } & 16\end{array}$

4 Apresentação e análise dos resultados $\quad 17$

4.1. Apresentação dos dados 17

$\begin{array}{lll}\text { 4.1.1 Sobre os respondentes } & 17\end{array}$

$\begin{array}{lll}\text { 4.1.2 Conhecimento Financeiro } & 18\end{array}$

$\begin{array}{lll}4.1 .3 & \text { Atitude Financeira } & 18\end{array}$

4.1.4 Planejamento Financeiro 20

4.2. Análise dos resultados 21

5 Conclusões e recomendações para novos estudos 24 


\section{Lista de Tabelas}

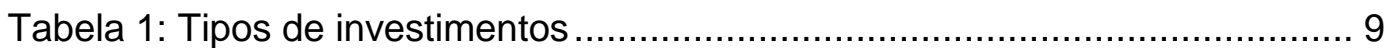

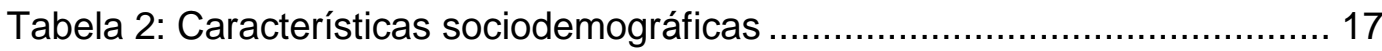

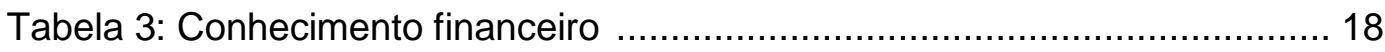

Tabela 4: Poupança/investimento ……………………………………...... 19

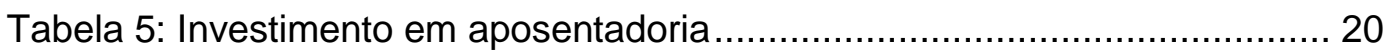

\section{Lista de Gráficos}

Gráfico 1: Gerenciamento do próprio dinheiro …............................................... 19

Gráfico 2: Atitude poupança/investimento ……………….......................... 20

Gráfico 3: Investimentos com foco na aposentadoria ....................................... 21

Gráfico 4: Investimentos além da aposentadoria ................................................. 21 


\section{Introdução ao tema e ao problema do estudo}

Segundo o INSS (2015), 99\% dos aposentados no Brasil não atingem a independência financeira, desse percentual, $33,9 \%$ dos aposentados ainda trabalham e $46,9 \%$ considera os ganhos oriundos da aposentadoria insuficiente para pagar as contas e as despesas pessoais. Um estudo feito pelo Serviço de Proteção ao Crédito (SPC), em 2016, indicou que $35,1 \%$ das pessoas com idade superior a 60 anos não se preparou de forma alguma para a aposentadoria. $O$ estudo concluiu também que existe certo grau de deficiência no nível de educação financeira da população brasileira, embora não falte informações sobre esse tema. Essa defasagem é reforçada através da pesquisa, feita em 2014, pela S\&P Ratings Services Global Financial Literacy Survey, revelando que o Brasil se encontra na $74^{a}$ posição do ranking mundial de educação financeira, atrás de países muito subdesenvolvidos como Zimbábue e Madagascar.

Segundo a Organização para a Cooperação e Desenvolvimento Econômico (OCDE), o tema da educação financeira vem se tornando cada vez mais importante para os governos nacionais, fazendo com que eles se concentrem cada vez mais em desenvolver estratégias focadas nesse assunto. A OCDE informa de que existem grande implicações sociais e econômicas a longo prazo sobre o baixo índice de educação financeira da população mundial, sendo esse o fator principal que leva os governos mundiais a se preocuparem com o tema. Até 2013, 45 países já desenvolveram estratégias relacionadas a esse tema ou já avançaram em projetos relacionados a alfabetização financeira.

O termo educação financeira é definido segundo a OCDE (2005), como o processo mediante 0 qual os indivíduos e as sociedades melhoram a sua compreensão em relação aos conceitos e produtos financeiros, de maneira que, com informação, formação e orientação, possam desenvolver os valores e as competências necessários para se tornarem mais conscientes das oportunidades e riscos neles envolvidos e, então, poderem fazer escolhas bem informadas, saber onde procurar ajuda e adotar outras ações que melhorem o seu bem-estar. Na mesma linha Anderloni e Vandone (2010) dizem que a educação financeira é entendida como uma medida preventiva, permitindo que 
os indivíduos tenham condições de entender problemas financeiros e gerenciar suas finanças pessoais de forma satisfatória, evitando o endividamento.

A importância da aposentadoria ficou muito forte no Brasil atualmente após as novas tentativas da reforma da previdência. Tal pauta vem sendo assunto de muita polêmica e revolta por boa parte da população Brasileira, visto que cada dia vai ficando mais difícil para os trabalhadores se aposentarem através da previdência social. Kiyosaki reforça dizendo que a ideia de trabalhar duro e esperar que ao ficar mais velho, o governo irá cuidar da população é uma ideia retrógada, da Era Industrial e que estamos na Era da Informação, onde as regras são diferentes. Kyosaki afirma ainda que se quisermos ter um futuro sólido na Era da Informação, precisamos assumir o controle da nossa fonte de renda, através de um planejamento financeiro adequado e da aquisição de ativos que geram renda.

Baseado nisso, é mais que importante, na atual conjuntura econômica, que entre em discussão maneiras de desenvolver a educação financeira da população, para que assim possam viver uma velhice mais estável e prazerosa. Segundo uma pesquisa realizada pelo Serviço de Proteção ao Crédito (SPC, 2017), 40\% dos jovens no Brasil não se preparam para a aposentadoria. Sabendo que esse percentual continua sendo alarmante, resta a seguinte pergunta: Será que os nossos jovens estarão se preparando para a aposentadoria? Qual é o grau de conhecimento e comportamento financeiro dos jovens? Partindo dessa pergunta, o estudo irá buscar entender o nível de conhecimento financeiro de um grupo de jovens universitários do Rio de Janeiro.

\subsection{Objetivo do estudo}

O Objetivo principal desse estudo é identificar se os jovens estão se preparando para a aposentadoria.

\subsection{Objetivos intermediários do estudo}

Para se atingir o objetivo final proposto, o estudo pretende:

1) Identificar o nível de conhecimento financeiro dos jovens universitários.

2) Entender como os jovens se comportam financeiramente.

3) Descobrir se os jovens fazem um planejamento financeiro das suas finanças. 


\subsection{Delimitação do estudo}

Esse estudo volta-se especificamente para abordar o nível de conhecimento financeiro dos jovens e sua preparação de longo prazo para a aposentadoria.

O grupo escolhido para a análise é composto por jovens universitários e recém-formados pertencentes a cidade do Rio de Janeiro, região sudeste do Brasil.

Embora seja relevante tratar o conhecimento financeiro como um todo, o presente estudo irá focar no conhecimento financeiro voltado a investimentos e 0 seu planejamento de longo prazo para a aposentadoria.

\subsection{Justificativa e relevância do estudo}

O estudo em questão visa colaborar para entender as possíveis causas que levam os jovens a não cuidarem das suas finanças. Além disso traz contribuições para os órgãos governamentais e a academia, pois o estudo vai ajudar a conhecer um pouco mais como os jovens se comportam financeiramente e isso pode influenciar futuramente na economia do país, além de chamar atenção do ensino da educação financeira nas universidades.

Por fim, o estudo pode contribuir para uma pesquisa mais aprofundada para buscar soluções que ajudem a instruir os jovens brasileiros, financeiramente. 


\section{Revisão de literatura}

\subsection{Educação Financeira no Brasil}

O conselho consultivo de alfabetização financeira (Presidents Advisory Council on Financial Literacy,2008) define alfabetização financeira como a capacidade de usar os conhecimentos e habilidades de gestão financeira de forma eficiente proporcionando bem-estar financeiro do indivíduo. E educação financeira é definida como o processo pelo qual as pessoas melhoram sua compreensão de produtos, serviços e conceitos financeiros, as capacitando para fazer escolhas informadas, evitando armadilhas e ajudando a tomar ações que melhorem o bem-estar financeiro presente e a longo prazo.

A Organização para a Cooperação e Desenvolvimento Económico (OCDE, 2005) define educação financeira como o processo mediante o qual os indivíduos e as sociedades melhoram a sua compreensão em relação aos conceitos e produtos financeiros, de maneira que, com informação, formação e orientação, possam desenvolver os valores e as competências necessários para se tornarem mais conscientes das oportunidades e riscos neles envolvidos e, então, poderem fazer escolhas bem informadas, saber onde procurar ajuda e adotar outras ações que melhorem o seu bem-estar.

A alfabetização financeira vem sendo cada dia mais reconhecida pela sua importância para o desenvolvimento econômico-financeiro e social, pelos países pertencentes ao G20 (OCDE, 2013). No Brasil foram criados órgãos para ajudar no desenvolvimento da educação financeira da população, como a Estratégia Nacional de Educação Financeira (Enef), fundada em 2010, que tem o objetivo de promover a educação financeira e contribuir para o fortalecimento da cidadania, para a eficiência e a solidez do Sistema Financeiro Nacional e para a tomada de decisões conscientes por parte dos consumidores. Além do Enef, foi criado o Comitê Nacional de Educação Financeira (Conef), que é responsável por definir planos, programas e ações e por coordenar a execução da Enef.

Conforme o relatório analítico da Enef (2013), o contexto socioeconômico do País, que cresceu a uma taxa média anual superior a 3,5\% na década passada, permitindo que milhões de pessoas participassem ativamente de um 
mercado de consumo antes inacessível para parte dos brasileiros, reforçou a importância de reunir novas e mais aprofundadas informações sobre os projetos e as ferramentas educacionais que estavam sendo oferecidas à população.

Segundo a Enef, em 2013 existiram 803 iniciativas, quase oito vezes maior que em 2010, com o objetivo de orientar o público em geral e financeiro, quanto oferecer informações ao cidadão sobre o planejamento financeiro, investimento, direitos, consumo consciente, visando ao fortalecimento do sistema financeiro nacional. Sendo desse total de iniciativas, $70 \%$ pertencentes a empresas do setor público e privado e $60 \%$ gratuitas.

Embora tenha aumentado o número de iniciativas voltadas para instruir financeiramente a população, apenas $30 \%$ dos brasileiros são poupadores ativos (OCDE, 2016). Desse total, 58\% não sabem quais investimentos contam com as melhores taxas de retorno, e a poupança, mesmo sendo a menos indicada, principalmente após o período de crise, no qual a inflação superava a taxa da poupança, é onde se concentra a maior parte do capital dos brasileiros (61\% dos poupadores). Segundo o SPC Brasil (2017), os outros investimentos escolhidos pelos Brasileiros são em imóveis (18\%), previdência privada (13\%), fundos de investimento (9\%), dólar (6\%) e CDB (5\%).

A falta de conhecimentos básicos sobre finanças e desconforto com a ideia de investir, fazem com que os brasileiros poupem pouco, influenciando diretamente no planejamento financeiro de longo prazo, como a aposentadoria. (Enef, 2010).

\subsection{Comportamento Financeiro}

Comportamento financeiro é definido como a forma de se comportar do indivíduo, que gera um resultado de grande relevância sobre o seu bem-estar financeiro (Atkinson, A. e Messy, F., 2012).

Ele, junto com a atitude financeira e o conhecimento financeiro formam a alfabetização financeira (OCDE, 2013), que é definido como a capacidade de compreender a informação financeira e tomar decisões eficazes, utilizando essa informação (ROBB; BABIARZ; WOODYARD, 2012).

Segundo Atkinson e Messy (2012), os resultados positivos de ser financeiramente alfabetizado são movidos pelo comportamento, como por exemplo, o planejamento de despesas, a construção da segurança financeira e as escolhas de produtos financeiros, por outro lado, certos comportamentos, 
como o uso excessivo de crédito e gastar mais do que ganha, podem reduzir o bem-estar financeiro.

Uma pesquisa feita pela Serasa Experian (2015) constatou que os brasileiros, embora tenham aumentado o seu conhecimento financeiro, o mesmo não é refletido em seu comportamento. O subíndice Conhecimento, que compõe o Indicador de Educação Financeira (IndEF), atingiu nota 7,7, que foi o maior índice dos últimos 3 anos. Em contrapartida, a nota do Comportamento em relação às finanças ficou em 5,5 .

De acordo com Moore (2003), um indivíduo alfabetizado financeiramente acaba tendo um bom conhecimento financeiro, atitude financeira positiva e comportamento financeiro adequado. Consequentemente, é eficaz na sua gestão financeira. (POTRICH, 2015)

\subsection{Planejamento Financeiro}

Planejamento financeiro estabelece como os objetivos financeiros devem ser alcançados (Ross, Westerfield, Jordan, 2013). Para Frankenberg (1999) significa estabelecer e seguir uma estratégia que permita acumular bens e valores que formarão o patrimônio de uma pessoa ou família. Giareta (2011) diz que além do acúmulo de reservas que ajudarão na realização dos objetivos dos diferentes períodos de vida do indivíduo, o planejamento financeiro proporciona uma segurança em casos de reveses financeiros, como desemprego.

O Banco Central, em seu programa chamado de Cidadania Financeira, afirma que para ter um bom planejamento financeiro, é necessária organização em toda a movimentação de recursos, como por exemplo receitas, despesas e investimentos. Além disso, o Sebrae, em sua cartilha de planejamento financeiro pessoal (2013) informa que é necessário ter metas claras e objetivas para curto e longo prazo e um plano de ação definido para que o objetivo possa ser alcançado.

Planejamento financeiro de curto prazo, segundo Gitman (1997), são ações planejadas para um período curto, que varia de um a dois anos, acompanhado da previsão dos seus reflexos financeiros. Já o planejamento financeiro de longo prazo, são ações financeiras projetadas para um futuro distante, que variam de dois a dez anos, acompanhado por seus reflexos financeiros (Gitman, 1997).

Uma pesquisa feita pelo SPC Brasil (2016) indicou que seis em cada dez pessoas têm dificuldade de fazer o planejamento financeiro mensal, sendo que 
sem o equilíbrio entre a renda e as despesas pessoais, 33\% acabam recorrendo a empréstimos. Além disso, a pesquisa indicou que $42 \%$ das pessoas se consideram inseguras a respeito de seus conhecimentos para administrar as suas finanças e gostariam de aprender mais sobre o assunto.

Em contrapartida, a maioria dos jovens no Brasil estão sabendo lidar com as suas finanças. $70 \%$ dos jovens entre 18 e 30 anos afirmam que planejam os seus gastos (SPC, 2016). De acordo com a pesquisa, 83,5\% dos jovens se consideram responsáveis com as finanças e 75,1\% garantem ser econômicos.

É importante que os jovens façam seu planejamento financeiro o mais rápido possível, pois geram melhores resultados financeiros e mais tempo para aproveitar de forma mais tranquila o período da aposentadoria (SEGUNDO FILHO, 2003). Corroborando com Segundo Filho, diversos autores, como Cherobim, Espejo e Paludo (2010), Gitman e Joehnk (2005), Veiga (2010) e Macedo Junior (2010), concordam que é importante poupar e investir o mais cedo possível.

Filho (2003) e Halfeld (2007) afirmam que existem duas fases no ciclo de vida de um indivíduo. Na primeira, durante a juventude, é necessário determinar objetivos bem específicos, poupar, assumir riscos controlados e adquirir seguros. Já na segunda fase, próxima da aposentadoria, é necessário tomar uma estratégia mais conservadora com relação aos seus investimentos.

Já Frankenberg (1999) defende que existem 3 principais fases no ciclo de vida do indivíduo para o planejamento financeiro de seus investimentos, que são juventude, idade adulta e velhice.

No período de juventude, Peretti (2008) e Frankenberg (1999) concordam que é uma fase no qual o jovem pode tomar uma postura mais agressiva e se aventurar em tipos de investimentos mais arriscados, pois em caso de perca de capital, ainda existe tempo para acumulação de patrimônio. Nessa fase é importante que o jovem também tenha uma parte alocada em investimentos mais conservadores e com mais liquidez, visto que ele tem mais despesas de médio prazo como estudos, e compra do carro próprio.

$\mathrm{Na}$ idade adulta, os investimentos precisam ser tomados com mais cautela, porém uma parte ainda pode ser alocada para investimentos mais arriscados. É importante também que se faça o mínimo de mudança de investimentos nessa fase. Nesse estágio, a maior parte do patrimônio deve estar alocada em investimentos de renda fixa e uma parte menor em renda variável.

Já na velhice é importante ser o mais conservador possível, Cherobim, Espejo e Paludo (2010) afirmam que nessa fase da vida não se pode perder 
patrimônio e o perfil de investimento com a grande maioria de capital devem ser de origem conservadora, como renda fixa.

\subsection{Importância de poupar e investir}

Existe uma ligação entre renda, consumo e poupança, visto que a renda que o indivíduo irá ganhar no período da aposentadoria, será na proporção de quanto que foi poupado durante a sua fase ativa. Ou seja, a pessoa irá receber no futuro o equivalente ao montante que foi poupado no presente (GARCIA, 2005).

Filho (2003) e Cherobim (2010) afirmam que poupar é a primeira etapa do planejamento financeiro e que é necessário investir os recursos guardados. Isso é importante devido ao valor do dinheiro no tempo, no qual o real hoje, vale muito mais do que o real prometido no futuro (ROSS, WESTERFIELD E JORDAN, 2013). Os autores afirmam ainda que o montante aplicado a uma determinada taxa de juros hoje, valeria muito mais do que se tivesse mantido parado esse mesmo montante no futuro. Isso porque o efeito dos juros compostos não é grande no curto prazo, porém a longo prazo o acúmulo de capital torna-se surpreendente (ROSS, WESTERFIELD E JORDAN, 2013).

Para Bodie, Kane e Marcus (2000) o investimento significa o "comprometimento atual do dinheiro ou de outros recursos na expectativa de colher benefícios futuros". Gitman e Joehnk (2005) corroboram afirmando que o investimento é "qualquer instrumento em que os fundos podem ser aplicados com a expectativa de que gerarão rendimento positivo e/ou preservarão ou aumentarão o seu valor".

Kiyosaki e Lechter (2002) explicam que antes de começar a investir é necessário estabelecer os seus objetivos de investimento e após ter definido o objetivo, escolher o veículo de investimento mais adequado para o atingimento do mesmo, no período de tempo pré-estabelecido. Na próxima seção serão abordados alguns veículos financeiros que podem ajudar o investidor a chegar a sua meta. 


\subsection{Tipos de Investimento}

O tipo de investimento escolhido pelo investidor que visa acumular capital para a aposentadoria depende da idade no qual começa a poupa e a investir (DIETRICH, 2016). Cherobim, Espejo e Paludo (2010) explicam que se o investidor for jovem, ele pode adotar por opções com um risco maior, como por exemplo, o mercado de renda variável. Porém, ao chegar em uma idade próxima a aposentadoria, a opção mais adequada seria em investimentos mais conservadores, como por exemplo, o mercado de renda fixa.

$\mathrm{Na}$ tabela 1 encontram-se resumidas as principais características dos investimentos.

Tabela 1

\begin{tabular}{|c|c|c|}
\hline Investimentos & Principais Características & Autores \\
\hline Poupança & $\begin{array}{l}\text {-Investimento simples e popular. } \\
\text { - Aplica-se qualquer valor, sem incidência de imposto de } \\
\text { renda ou taxa de administração. } \\
\text { - Não indicado investimento para aposentadoria, pois } \\
\text { em longo prazo seu rendimento perde para a inflação. }\end{array}$ & $\begin{array}{l}\text { MEGLIORINI; } \\
\text { VALLIN, (2009) } \\
\text { LUQUET (2001) }\end{array}$ \\
\hline CDB's & $\begin{array}{l}\text { - São títulos de renda fixa emitidos pelos bancos, } \\
\text { adquiridos por investidores que os trocam em data } \\
\text { futura, } \\
\text { recebendo o valor investido mais a taxa de juros } \\
\text { pactuada } \\
\text { anteriormente. } \\
\text { - o risco do investimento é o risco de falência do banco } \\
\text { emissor. }\end{array}$ & $\begin{array}{c}\text { COMISSÃO DE } \\
\text { VALORES } \\
\text { MOBILIARIOS } \\
(2013) \\
\text { SEGUNDO } \\
\text { FILHO (2003) } \\
\text { MACEDO } \\
\text { JUNIOR (2010) }\end{array}$ \\
\hline $\begin{array}{l}\text { Títulos } \\
\text { Públicos }\end{array}$ & $\begin{array}{l}\text { - São ativos de renda fixa que têm o objetivo de financiar } \\
\text { a dívida pública e as atividades governamentais, são } \\
\text { emitidas pelo Governo Federal e comercializadas por } \\
\text { meio do Tesouro Direto. } \\
\text { - Existem diversas variedades de títulos públicos, } \\
\text { - Dividem-se em pré-fixados e pós-fixados, com } \\
\text { características diferentes } \\
\text { - Entre as principais vantagens, destacam-se a }\end{array}$ & $\begin{array}{l}\text { COMISSÃO DE } \\
\text { VALORES } \\
\text { MOBILIARIOS } \\
\text { (2013) }\end{array}$ \\
\hline
\end{tabular}




\begin{tabular}{|l|l|r|}
\hline & $\begin{array}{l}\text { segurança, } \\
\text { pois o investimento é garantido pelo governo, e a } \\
\text { rentabilidade que é bastante competitiva frente a outros } \\
\text { tipos de investimento de renda fixa. }\end{array}$ & $\begin{array}{r}\text { FILHO (2003) } \\
\text { MACEDO } \\
\text { JUNIOR (2010) }\end{array}$ \\
\hline
\end{tabular}

Elaborado por Braido, G. M.; Dietrich, J (2016)

\begin{tabular}{|c|c|c|}
\hline Investimentos & Principais Características & Autores \\
\hline $\begin{array}{l}\text { Letra de } \\
\text { Crédito do } \\
\text { Agronegócio } \\
\text { (LCA), } \\
\text { Letra de } \\
\text { Crédito } \\
\text { Imobiliário } \\
\text { (LCI) }\end{array}$ & $\begin{array}{l}\text { - São investimentos novos (LCl criada pela Lei n } 10.931 \\
\text { e LCA Lei no } 11.076 \text { ambas de 2004). } \\
\text { - Por serem investimentos livres de Imposto de renda e } \\
\text { cobertos pelo Fundo Garantidor de Crédito apresentam } \\
\text { grande crescimento nos últimos anos. } \\
\text { - A LCA é lastreada a operações de credito rural e a LCl } \\
\text { é } \\
\text { lastreada a operações de crédito imobiliário, portanto o } \\
\text { investidor assume o risco primário da instituição } \\
\text { emissora. }\end{array}$ & CETIP (2015) \\
\hline Investimentos & Principais Características & Autores \\
\hline $\begin{array}{l}\text { Fundos de } \\
\text { Investimento }\end{array}$ & $\begin{array}{l}\text { - São condomínios formados com o intuito de realizar } \\
\text { uma aplicação coletiva dos participantes. } \\
\text { - São uma forma coletiva de investimento, que auxilia o } \\
\text { pequeno investidor individual. } \\
\text { - São classificados por categorias que dividem os fundos } \\
\text { conforme o tipo de investimento que cada um realiza, } \\
\text { facilitando para o investidor optar por um fundo mais } \\
\text { adequado ao seu perfil de investimento. }\end{array}$ & $\begin{array}{l}\text { COMISSÃO DE } \\
\text { VALORES } \\
\text { MOBILIÁRIOS } \\
\text { (2013) } \\
\text { ANBIMA (2014) }\end{array}$ \\
\hline Ações & $\begin{array}{l}\text { - Ações são a menor parte do capital social de uma } \\
\text { companhia ou sociedade por ações, é um título } \\
\text { patrimonial que concede aos acionistas direitos e } \\
\text { deveres de um sócio da empresa. } \\
\text { - Os acionistas participam do resultado da companhia } \\
\text { por meio do recebimento de dividendos e bonificações. } \\
\text { Além disso, o investidor pode obter ganho com a venda } \\
\text { de ações que possam ter sofrido valorizações. Essa } \\
\text { valorização não é garantida, pelo contrário, a } \\
\text { desvalorização da ação também pode ocorrer, portanto, } \\
\text { o investimento em ações é considerado como renda } \\
\text { variável e está sujeito ao risco de mercado da } \\
\text { companhia e ao risco econômico do mercado. } \\
\text { - Mesmo sendo um investimento de renda variável, } \\
\text { consideram-se as ações como um dos melhores }\end{array}$ & $\begin{array}{l}\text { COMISSÃO DE } \\
\text { VALORES } \\
\text { MOBILIÁRIOS } \\
\text { (2013) } \\
\text { LUQUET (2001) }\end{array}$ \\
\hline
\end{tabular}




\begin{tabular}{|c|c|c|}
\hline & $\begin{array}{l}\text { investimentos de longo prazo para a aposentadoria, pois } \\
\text { elas tendem, no longo prazo, pagar um prêmio por } \\
\text { investir em um mercado de maior risco que a renda fixa. }\end{array}$ & \\
\hline $\begin{array}{l}\text { Previdência } \\
\text { privada } \\
\text { complementar } \\
\text { aberta } \\
\text { (continuação) }\end{array}$ & $\begin{array}{l}\text { É regulamentada e fiscalizada pela Superintendência de } \\
\text { Seguros Privados (Susep), autarquia federal regulada } \\
\text { pelo Conselho Nacional de Seguros Privados (CNSP) e } \\
\text { que está ligada ao Ministério da Fazenda. } \\
\text { - É organizada de forma autônoma à Previdência Social. } \\
\text { - Os planos de previdência privada complementar aberta } \\
\text { mais populares são o Plano Gerador de Benefício Livre } \\
\text { (PGBL) e o Vida Gerador de Benefício Livre (VGBL), } \\
\text { ambos podendo ser comercializados por entidades } \\
\text { abertas de previdência complementar (EAPC's) ou } \\
\text { sociedades seguradoras. } \\
\text { - O PGBL é um plano em que o investidor escolhe o } \\
\text { valor } \\
\text { e a frequência das contribuições. Sua principal } \\
\text { característica é o benefício fiscal, com os aportes no } \\
\text { PGBL é possível abater até } 12 \% \text { da renda tributável do } \\
\text { imposto de renda, porém, no momento do resgate o } \\
\text { imposto de renda incidirá sobre o valor total, aplicação } \\
\text { mais rendimentos. } \\
\text { - O VGBL é um seguro de pessoas com cobertura por } \\
\text { sobrevivência, tem muitas características semelhantes a } \\
\text { um PGBL, mas se diferencia pelo fato de que suas } \\
\text { contribuições não podem ser deduzidas do imposto de } \\
\text { renda, em contrapartida no momento do resgate o } \\
\text { imposto de renda incide somente sobre o rendimento do } \\
\text { capital aplicado. } \\
\text { - Incidem taxas de administração e de carregamento } \\
\text { sobre o investimento. }\end{array}$ & $\begin{array}{c}\text { MARTINS; } \\
\text { LAZARRI; } \\
\text { MARTINS (2006) } \\
\text { CHEROBIM; } \\
\text { ESPEJO; } \\
\text { PALUDO (2010) } \\
\text { LUQUET (2001) }\end{array}$ \\
\hline
\end{tabular}

Elaborado por Braido, G. M.; Dietrich, J (2016)

\subsubsection{PGBL e VGBL}

O Instituto Brasileiro de Geografia e Estatística (IBGE, 2015) informou que a expectativa de vida do Brasileiro é de 75,5 anos. Partindo dessa informação, Frankenberg (1999) afirma que é importante que o indivíduo planeje para que entre o período de aposentadoria e falecimento, ele tenha uma renda suficiente para poder viver a terceira idade de uma forma mais cômoda e digna.

Porém, mais de $60 \%$ dos brasileiros não faz reserva nenhuma para aposentadoria, tendo como única contribuição o INSS (SPC, 2016). Dos entrevistados pelo Serviço de Proteção ao Crédito (SPC), apenas 6,2\% 
contribuiu para algum programa de previdência privada e $19,2 \%$ colocam dinheiro na poupança.

É necessário que exista uma mudança, por parte dos brasileiros, na preocupação com a aposentadoria, devido a três fatores, que são listados por Frankenberg (1999). O primeiro seria a necessidade de capital e de renda mensal para o sustento do aposentado, durante esse período no qual ele não é mais uma pessoa economicamente ativa. Em segundo lugar, cada vez mais as famílias estão tendo menos filhos, logo a taxa de natalidade diminui, reduzindo também a quantidade de contribuintes da previdência social, que consequentemente torna insustentável o modelo do INSS. Em terceiro Lugar, as novas tecnologias que estão surgindo no mundo, com foco no aperfeiçoamento da eficiência das organizações, vêm aumentando o desemprego que acarreta também na diminuição da arrecadação da previdência oficial do Estado.

Devido a esses fatores, iremos focar em dois tipos de produtos financeiros voltados para a aposentadoria, que são o Plano Gerador de Benefícios Livres (PGBL) e a Vida Gerador de Benefício Livre (VGBL).

O Plano Gerador de Benefícios Livres é um produto financeiro oferecido por bancos, seguradoras e empresas de previdência complementar, com o foco em ser uma alternativa para a complementação da aposentadoria. O PGBL não possui garantia mínima de rendimento e permite que o investidor escolha o perfil de risco do seu interesse, baseado no seu horizonte de investimento (FORTUNA, 2002).

Existem 3 modalidades de PGBL que o cliente pode escolher que são o Plano Soberano, Plano de Renda Fixa e Plano Composto. O Plano Soberano consiste em aplicações dos recursos em apenas títulos públicos. O Plano de Renda Fixa aloca o capital em títulos públicos e outros investimentos de renda fixa e o Plano Composto diversifica entre títulos públicos e renda fixa e até $49 \%$ do capital investido em renda variável.

As contribuições ao PGBL podem ser fixas ou variáveis, podendo aceitar depósitos adicionais e os custos ao investidor são da taxa de administração e a taxa de contribuição que é descontada sobre cada aplicação do investidor. Além disso não é pago imposto de renda sobre os ganhos de capital, como costuma acontecer nos demais fundos de renda fixa.

O VGBL, assim como o PGBL é oferecido por bancos, seguradoras e empresas de previdência complementar, mas não possui garantia de remuneração mínima e de atualização de valores (FORTUNA, 2002). 
Assim como o PGBL, existem 3 modalidades do $\mathrm{VGBL}$, que são 0 Soberano (VGBL-S), Renda Fixa (VGBL-RF) e Composto (VGBL-C). Os custos são a taxa de carregamento e de administração. Esse tipo de previdência é mais recomendado para o investidor que já possui um plano de sucessão definido. 


\section{Métodos e procedimentos de coleta e de análise de dados do estudo}

\subsection{Tipo de pesquisa realizada}

Dado o objetivo presente da pesquisa, foi utilizado o método de pesquisa exploratória. Segundo Malhotra (2012, p.59), essa pesquisa tem como objetivo explorar ou fazer uma busca em um problema ou em uma situação, a fim de oferecer informações e maior compreensão.

No caso deste trabalho, pretende-se entender o nível de educação financeira dos jovens universitários do Rio de Janeiro e saber se eles estão se planejando no longo prazo, para a aposentadoria.

Além de ser exploratória a pesquisa é de cunho quantitativo, pois procura quantificar dados, além de buscar uma evidência conclusiva, através de amostras grandes e para também utilizar uma análise estatística, podendo ser tratadas como conclusivas e utilizadas para recomendar um curso de ação final. (MALHORTA, 2006, p. 114)

Para fazer a pesquisa foi utilizado um questionário com perguntas majoritariamente fechadas, conforme mostra o anexo 1.

\subsection{Fontes de informação selecionadas para coleta de dados no estudo}

A amostra da pesquisa foi escolhida por conveniência. O questionário foi divulgado com uma pré-seleção dos correspondentes, pois a pesquisa tinha como foco estudantes universitários em formação ou recém-formados, no Rio de Janeiro.

Dessa amostra selecionada foram coletadas 133 respostas, já desconsiderando fora os correspondentes do perfil necessário. 


\subsection{Procedimentos e instrumentos de coleta de dados utilizados no estudo}

As respostas foram coletadas através do Qualtrics, que é um sistema de pesquisa disponibilizado pela PUC-Rio. O questionário é composto por 20 perguntas, sendo 17 fechadas e 3 abertas.

O primeiro bloco do questionário, Sobre Você, é composto por 6 questões, com foco em identificar o perfil do correspondente. As perguntas desse bloco são de cunho demográfico, para saber o sexo, nível de escolaridade, curso e renda mensal individual.

O segundo bloco do questionário, Educação Financeira, tem como objetivo entender como está o conhecimento financeiro básico dos jovens universitários. Esse bloco é composto por 3 questões e contém perguntas sobre rendimento de aplicações, inflação e valor do dinheiro no tempo. As questões desse bloco foram retiradas do questionário do estudo feito por POLTRICH, 2016 na seção sobre conhecimento financeiro.

O terceiro bloco do questionário, Investimentos, é composto por 5 questões, com o objetivo de entender o nível de conhecimento sobre os tipos de investimentos existentes. Esse bloco contém perguntas sobre diversificação, CDB, títulos públicos, investimentos com maior oscilação e investimentos que dão maior retorno no longo prazo. As questões desse bloco foram retiradas do questionário do estudo feito por POLTRICH, 2016 na seção sobre conhecimento financeiro.

O quarto bloco do questionário, Planejamento Financeiro e Aposentadoria, é composto por 6 questões, com o foco em identificar se os jovens universitários se sentem confortáveis em investir, se já fazem planejamento financeiro com foco na aposentadoria e se já investem em algum produto financeiro. Esse bloco contém perguntas sobre poupança e investimento mensal, conhecimento financeiro, tipos de aplicações feitas em produtos financeiros e investimentos feitos com foco na aposentadoria. As questões 15 e 17 foram retiradas do questionário do estudo feito por LUCCI; ZERRENNER; VERRONE e SANTOS.

Foi feito um pré-teste para duas pessoas, através do link do Qualtrics. Esse pré-teste tinha como objetivo verificar se as perguntas estavam claras, se conseguiam responder as perguntas sem o uso da calculadora e também para ver se o questionário não ficava cansativo demais para ser respondido. Os dois respondentes deram feedbacks positivos sobre os aspectos que estavam sendo testados e, logo após o questionário foi circulado. 
O link foi enviado para os respondentes através de mídias sociais, professores de finanças da universidade e amigos com maior popularidade.

O questionário ficou aberto para respostas do dia 13 de outubro até o dia 20 de outubro, com um total de 200 respostas.

Desse total, 67 respostas foram descartadas, ou por não fazer parte do público alvo ou não ter respondido o questionário completo. Logo, o total de respostas válidas foi 133 .

\subsection{Formas de tratamento e análise dos dados coletados para o estudo}

Os dados foram coletados através de um questionário feito no qualtrics. Em um primeiro momento foi utilizado as informações do relatório do próprio sistema, porém devido a uma dificuldade de fazer o cruzamento entre as informações obtidas, os dados foram exportados para o excel.

O cruzamento das informações em cada bloco tem como objetivo entender o nível de conhecimento financeiro, o quanto o jovem se sente confiante a fazer os investimentos e a se planejar e a preocupação com a aposentadoria.

A partir desse processo, foi possível fazer a análise das informações apresentadas no próximo capítulo.

\subsection{Limitações do Método}

Uma limitação a pesquisa é que a grande maioria da amostra foi coletada em uma única universidade do Rio de Janeiro, a PUC-Rio. Assim, a pesquisa pode ser pouco abrangente.

A segunda limitação do estudo é que a pesquisa foi enviada para os respondentes de forma virtual. Logo, não é possível garantir que os usuários não tenham utilizado calculadora ou tenham pesquisado alguma informação na internet. 


\section{Apresentação e análise dos resultados}

\subsection{Apresentação dos dados}

\subsubsection{Sobre os respondentes}

A participação dos respondentes, no que se refere ao gênero, foi praticamente igualitária, sendo 50,38\% masculino e $49,62 \%$ feminino. A faixa etária da amostra foi majoritariamente entre 18 e 25 anos (89\%), que fizeram ou estão cursando os cursos de administração e engenharia (71\%). A renda mensal individual dos respondentes foi de até $R \$ 1.244,00$ para $44 \%$ da amostra, de $R \$ 1.244,00$ a $R \$ 2.488,00$ para $32 \%$ da amostra e $R \$ 2.489,00$ a $R \$ 6.220$ para $14 \%$ dos respondentes.

As características sociodemográficas estão na tabela abaixo:

Tabela 2

\begin{tabular}{lrcc}
\hline & & \multicolumn{2}{c}{ Amostra } \\
\hline Amostra Total & & $(\mathrm{n})$ & $(\%)$ \\
\hline Sexo & & 133 & $100 \%$ \\
\hline Faixa Etária & Masculino & 67 & $50,4 \%$ \\
& Feminino & 66 & $49,6 \%$ \\
\hline Curso em andamento/feito & $18-21$ & 45 & $33,8 \%$ \\
& $22-25$ & 73 & $54,9 \%$ \\
& $26-30$ & 10 & $7,5 \%$ \\
& Acima de 30 & 5 & $3,8 \%$ \\
\hline Renda mensal individual & Administração & 66 & $49,6 \%$ \\
& Engenharia & 28 & $21,1 \%$ \\
& Direito & 5 & $3,8 \%$ \\
& Economia & 4 & $3,0 \%$ \\
& Outros & 30 & $22,6 \%$ \\
\hline
\end{tabular}




\subsubsection{Conhecimento Financeiro}

Dos 133 respondentes, apenas 22 acertaram as 6 questões relacionadas a conhecimentos básicos de finanças, das seções Educação Financeira e Investimentos.

As questões referentes a inflação tiverem 78,9\% de acerto, sobre juros compostos $73,7 \%$ de acerto, sobre diversificação $81,2 \%$ e sobre produtos financeiros $24,8 \%$.

\section{Tabela 3}

\begin{tabular}{|l|c|}
\hline \multicolumn{1}{|c|}{ Perguntas } & Acertos \\
\hline Sobre inflação - Questões 7 e 8 & $78,9 \%$ \\
\hline Sobre juros compostos - Questão 9 & $73,7 \%$ \\
\hline Sobre diversificação - Questão 10 & $81,2 \%$ \\
\hline Sobre produtos financeiros - Questão 11 a & $24,8 \%$ \\
\hline 13 & \\
\hline
\end{tabular}

Nas perguntas sobre os produtos financeiros, quando perguntados se quando uma pessoa compra um CDB ela está emprestando dinheiro para o banco, 65\%, acertaram a questão dizendo que era verdadeiro, 6\% disseram ser falso e $29 \%$ disseram que não sabiam. Ao perguntar sobre qual ativo normalmente oferece um retorno maior no longo prazo, como 10 anos por exemplo, $36 \%$ acertaram a questão dizendo ser ações, $41 \%$ disseram títulos públicos, $6 \%$ disseram poupança e $17 \%$ disseram que não sabia.

\subsubsection{Atitude Financeira}

Quando perguntados sobre quão seguro os respondentes estavam com relação aos seus conhecimentos financeiros para gerenciar o seu dinheiro, $62,5 \%$ dos entrevistados não sentiam segurança suficiente para gerenciar as suas finanças, sendo $22,6 \%$ se sentem nada seguros e acreditavam que precisavam aumentar muito o seu nível de educação financeira e 39,9\% dos entrevistados se sentem não muito seguros com relação aos seus conhecimentos e gostariam de aprender um pouco mais.

$37,5 \%$ dos entrevistados sentem alguma segurança para poder gerenciar as suas finanças. Desse total, $30,8 \%$ se consideram razoavelmente seguros com 
relação aos seus conhecimentos financeiros e 6,7\% se consideram com conhecimento aprofundado sobre os assuntos referentes as suas finanças e investimentos.

\section{Gráfico 1}

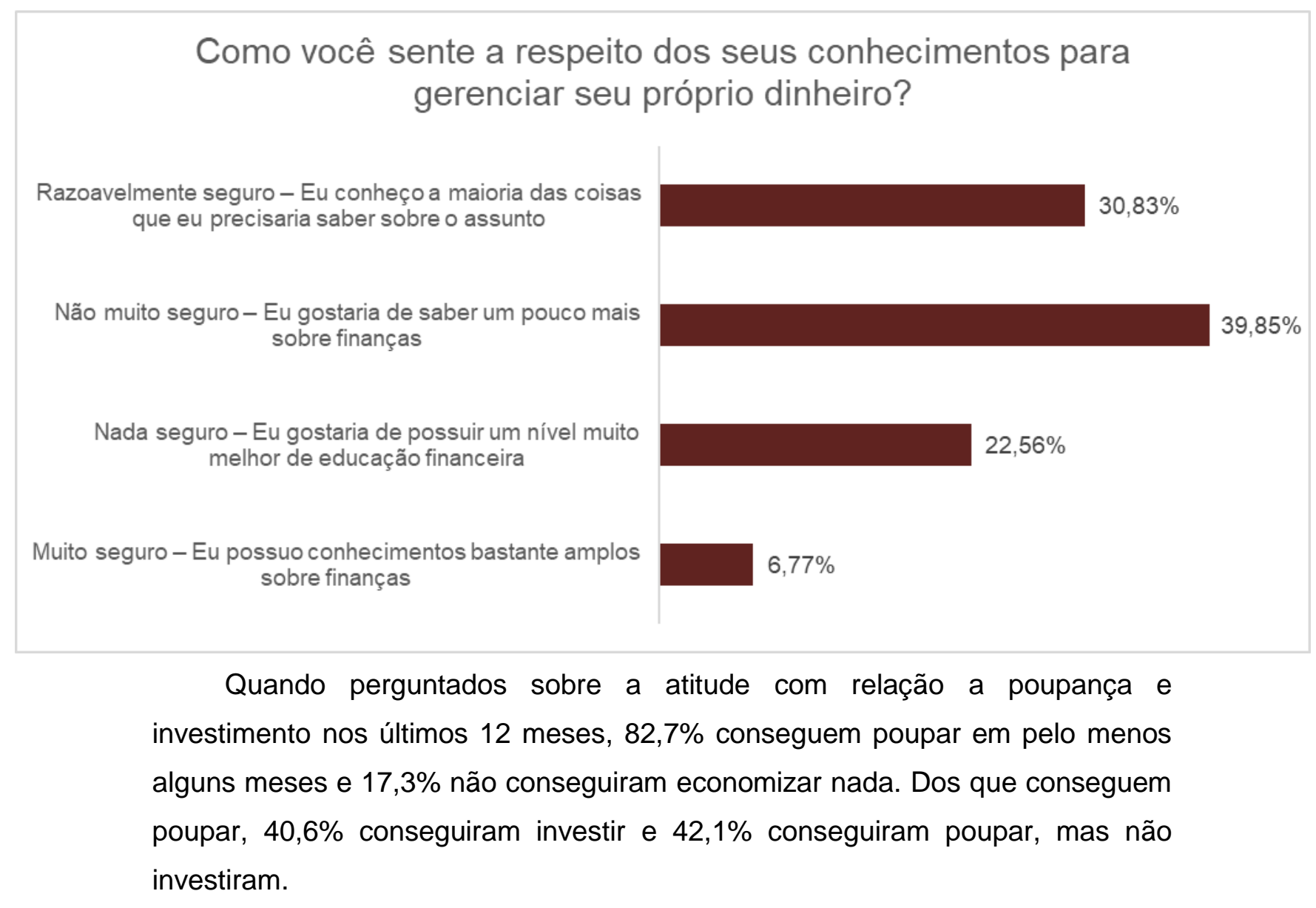

Tabela 4

\begin{tabular}{lrcc}
\hline & \multicolumn{2}{c}{ Amostra } \\
\hline Amostra Total & & (n) & $(\%)$ \\
\hline Atitude de Poupança/Investimento & 133 & $100 \%$ \\
& Pouparam no mín. alguns meses & 110 & $82,7 \%$ \\
& Não conseguiram economizar & 23 & $17,3 \%$ \\
\hline Conseguiram poupar & Conseguiram Investir & 54 & $40,6 \%$ \\
& Não investiram & 56 & $42,1 \%$ \\
\hline
\end{tabular}




\section{Gráfico 2}

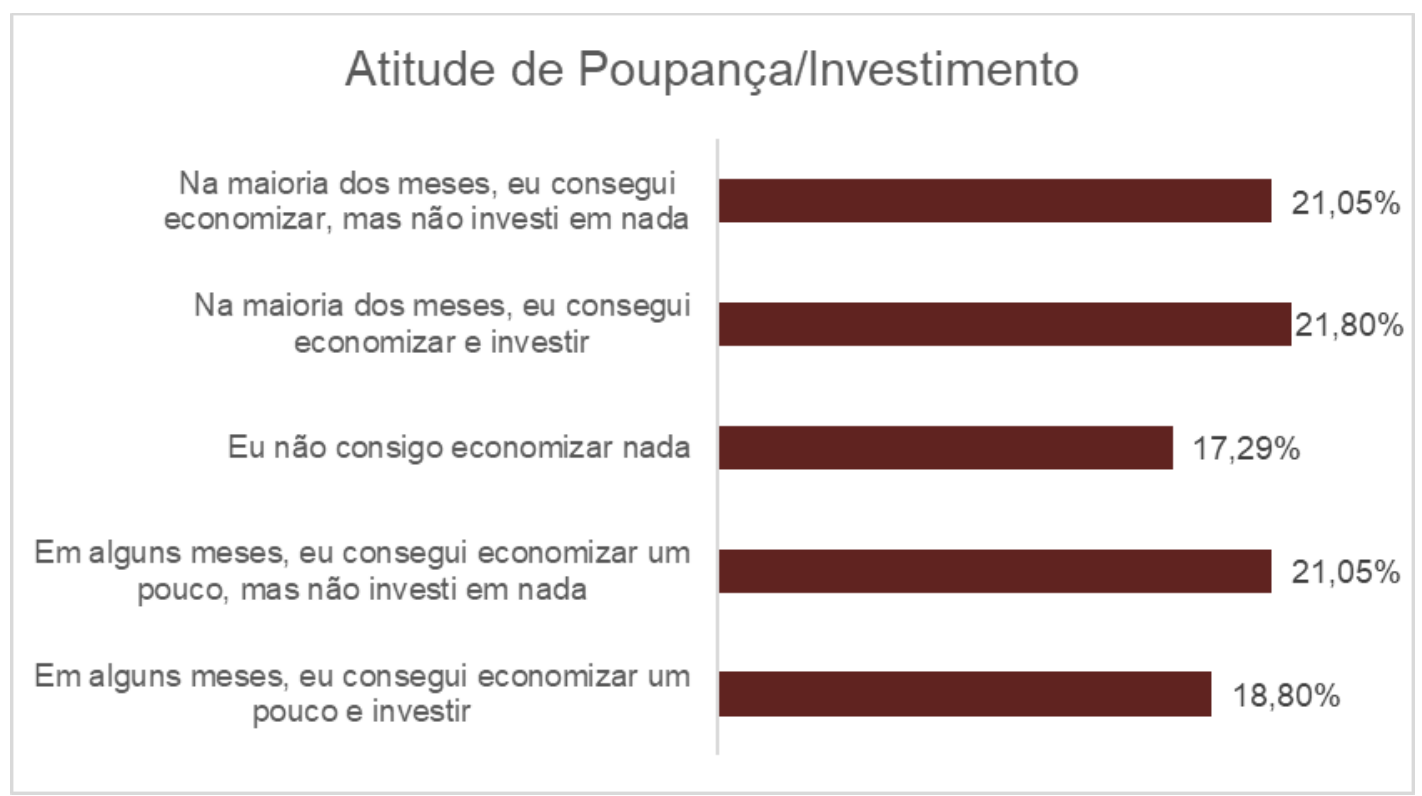

\subsubsection{Planejamento Financeiro}

No que se refere a aposentadoria, $75,2 \%$ dos entrevistados não se planejaram ainda para isso, ou porque não se preocuparam ainda com esse tema $(40,6 \%)$ ou tem planos para começar a poupar para isso (34,6\%). $21 \%$ dos jovens já fazem algum investimento com foco na aposentadoria, sendo através de previdência privada (15\%) ou através de outros produtos financeiros (6\%). Outros respondentes disseram que terão apenas a previdência social do Estado $(2,3 \%)$ ou não veem necessidade de poupar para a aposentadoria $(1,5 \%)$.

\section{Tabela 5}

\begin{tabular}{lrcc}
\hline & & \multicolumn{2}{c}{ Amostra } \\
\hline Amostra Total & & $(\mathrm{n})$ & $(\%)$ \\
\hline Aposentadoria & Não investe & 133 & $100 \%$ \\
& Investe & 100 & $75,2 \%$ \\
& Apenas INSS & 28 & $21,0 \%$ \\
& Não veem necessidade & 3 & $2,3 \%$ \\
& 2 & $1,5 \%$ \\
\hline
\end{tabular}

Dos que investem no longo prazo, com foco na aposentadoria, 15,9\% deixam o dinheiro aplicado na poupança, 11,4\% em títulos públicos, 4,6\% em CDB's, 4,6\% em LCl e LCA, 15,9\% em fundos de investimento, 36,4\% em previdência privada, $6,8 \%$ em ações e 4,6\% em nada além da previdência privada. 


\section{Gráfico 3}

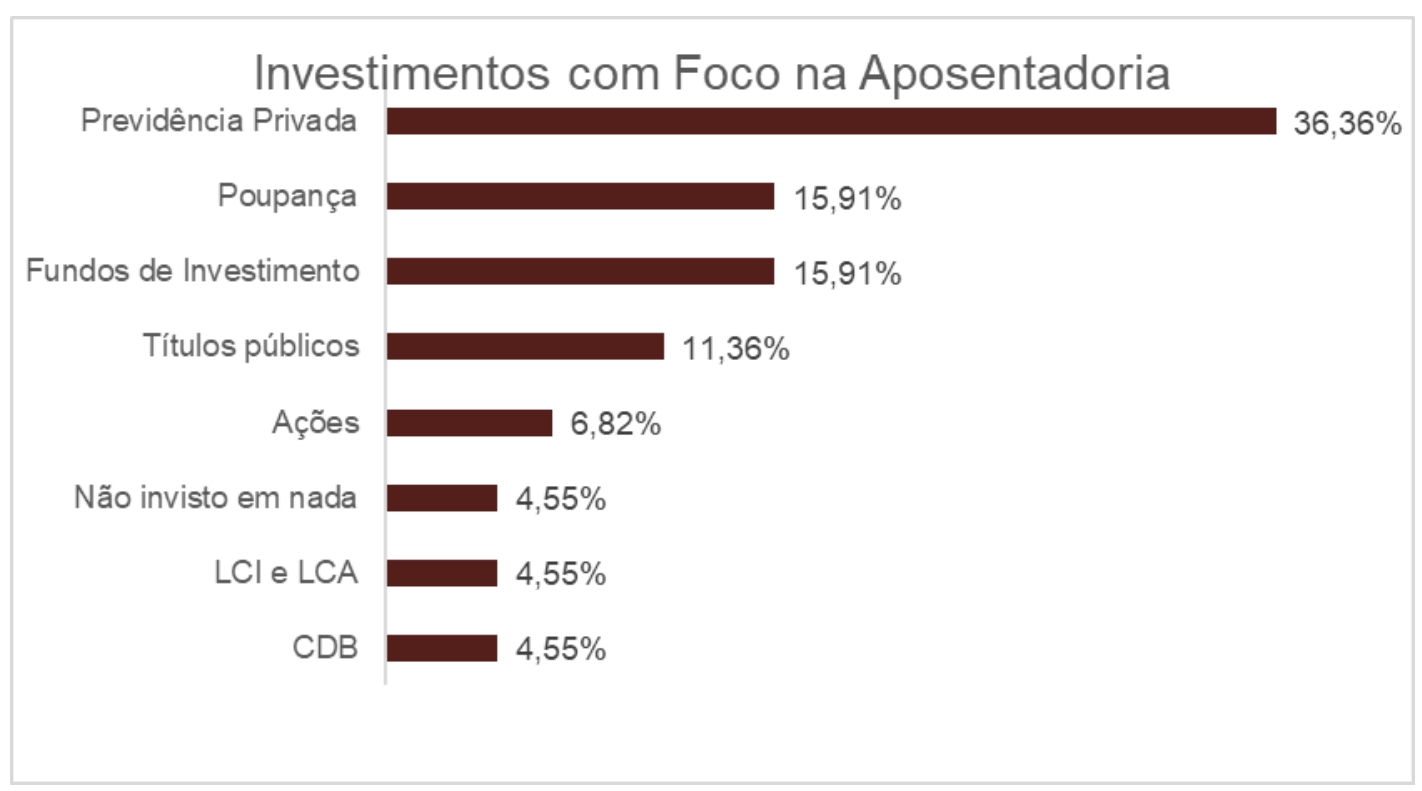

Fora os investimentos na aposentadoria, os entrevistados aplicam em poupança $(41,1 \%)$, títulos públicos $(6,5 \%)$, CDB's $(11,4 \%)$, LCl e LCA $(4,9 \%)$, fundos de investimento $(11,9 \%)$, ações $(6,5 \%)$ e não investe em nada $(17,8 \%)$.

\section{Gráfico 4}

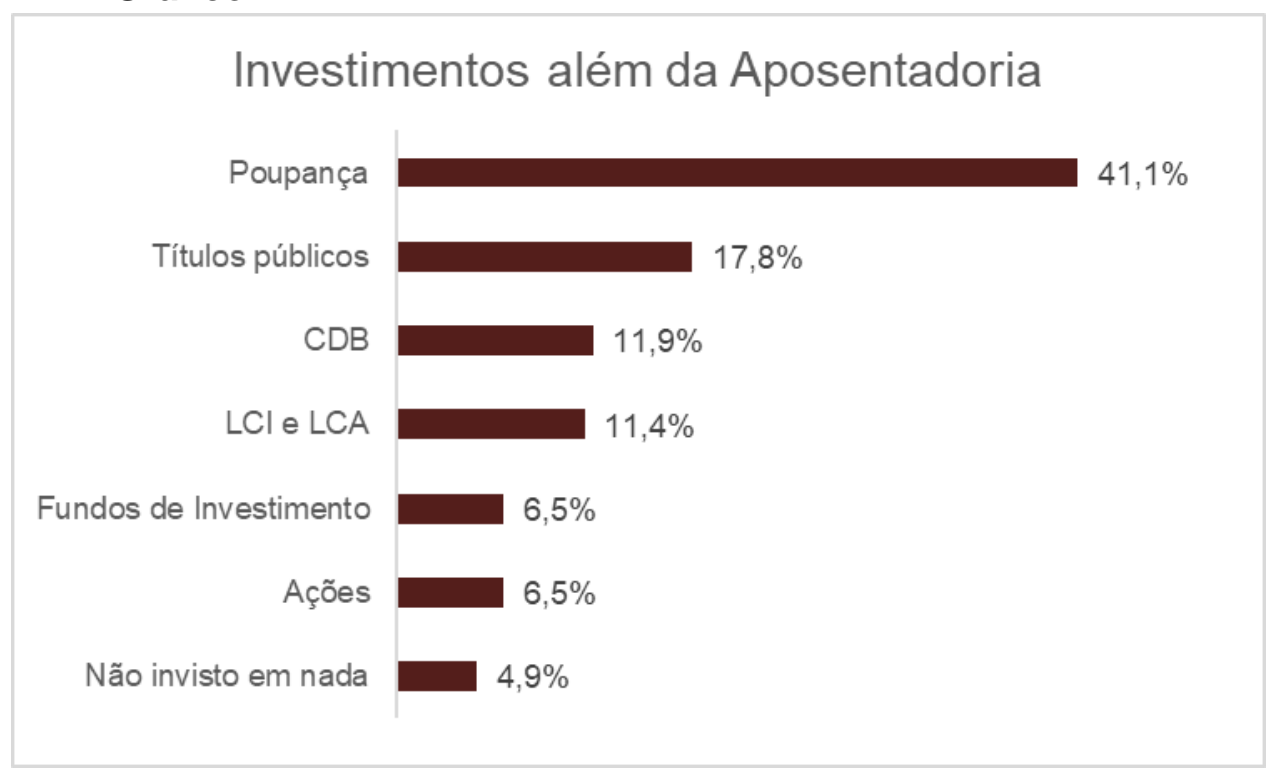

\subsection{Análise dos resultados}

A pesquisa exploratória feita por esse estudo tinha como objetivo entender o nível de conhecimento financeiro dos jovens e seu planejamento financeiro de longo prazo, com foco na aposentadoria. Para atingir esse objetivo, a partir dos resultados obtidos pelo questionário, foram cruzadas as informações obtidas 
entre as seções "Educação Financeira", "Investimentos" e "Planejamento Financeiro e Aposentadoria".

Das 6 questões relacionadas a conhecimento financeiro (questões 7 a 13), apenas poucas pessoas acertaram todas as questões, tendo como menor índice de acertos, as questões sobre os produtos financeiros. Esse percentual reforça outro resultado da mesma pesquisa que mostrava que a maioria das pessoas não se sentiam seguros sobre os seus conhecimentos financeiros e achavam que precisavam conhecer mais do assunto. Corroborando com o resultado do questionário, a pesquisa do SPC, em 2016, conforme apresentado na seção 2.3, dizia que $42 \%$ das pessoas se consideram inseguras a respeito de seus conhecimentos para administrar as suas finanças e gostariam de aprender mais sobre o assunto.

Partindo da definição de educação financeira pela OCDE (2005) e Giareta (2011), por não conhecer muito sobre os produtos financeiros, o investidor jovem acaba não sabendo aonde aplicar o seu dinheiro e aproveitar as oportunidades que possam melhorar o seu bem-estar e atingir os seus objetivos. Esse déficit de conhecimento financeiro pode colaborar para o ato de poupar e não investir em nada ou de até mesmo de gastar toda a renda mensal (Enef, 2010). Com os resultados obtidos pelo questionário, podemos ver que embora $82,7 \%$ dos entrevistados consigam poupar, 42,1\% conseguiram poupar, mas não investiram e $17,29 \%$ não conseguem poupar nada no final do mês. Filho (2003) e Cherobim (2010) dizem que não adianta apenas poupar e sim utilizar esse dinheiro guardado para investir, porque essa é a primeira etapa do planejamento financeiro.

No que se refere ao comportamento financeiro dos jovens com relação a aposentadoria, $75,2 \%$ dos jovens entrevistados ainda não se preocupam com a aposentadoria. Isso tem se mostrado uma tendência que vem aumentando, visto que $35,1 \%$ dos idosos não se prepararam de forma alguma para a aposentadoria (SPC, 2016) e 60\% dos brasileiros não fazem reserva para a aposentadoria, contando apenas com o INSS (SPC,2016).

Dos que se planejam para a aposentadoria, 36\% possuem alguma forma de previdência privada, 15,91\% usam fundos de investimento, 11,36\% em títulos públicos, $6,8 \%$ em ações e $9,1 \%$ em outros produtos de renda fixa. Porém, uma parte considerável ainda utiliza a poupança como um veículo para aposentadoria $(15,91 \%)$. Isso pode significar, como foi percebido anteriormente, a falta de conhecimento relacionado aos tipos de investimentos para a aposentadoria, 
impossibilitando assim de utilizar um veículo financeiro mais adequado para o objetivo desejado (KIYOSAKI e LECHTER, 2002).

Reforçando o que foi visto no parágrafo anterior, ao perguntar quais tipos de investimentos os respondentes tinham além da aposentadoria, a grande maioria ainda tem a maior parte de seu capital alocado em poupança (41\%), 17,8\% investem em títulos públicos, 11,9\% em CDB e 11,4\% em LCl ou LCA. Fundos de investimento e ações tiveram um percentual menor, ambas com $6,5 \%$. 


\section{Conclusões e recomendações para novos estudos}

O presente estudo analisou o nível de conhecimento financeiro e suas relações com investimentos e planejamento para a aposentadoria. Para realizar esse objetivo, foi feita uma pesquisa de campo com 133 estudantes universitários, do Rio de Janeiro, graduandos ou recém graduados.

O questionário foi elaborado através de pesquisas já construídas por POLTRICH, 2016 e LUCCI; ZERRENNER; VERRONE e SANTOS (2006) sobre conhecimento financeiro e aposentadoria. A amostra foi selecionada por conveniência.

O nível de conhecimento financeiro relacionado ao valor do dinheiro ao longo do tempo, efeito da inflação e juros compostos foi consideravelmente bom, contudo, ao aprofundar para o conhecimento relacionado aos produtos financeiros, percebemos que ainda falta muita familiaridade dos jovens. Adicionalmente, esse resultado se refletiu ao perguntar como os entrevistados se sentiam com relação aos seus conhecimentos financeiros e a maioria deles não se sentem seguros para gerir suas finanças. Tal resultado reflete na atitude desses jovens, que mantêm a maior parte ou todo o seu capital aplicado na poupança ao invés de buscarem alternativas que tenham uma rentabilidade maior e que se adequem aos seus objetivos pessoais

Corroborando com o parágrafo anterior, a grande maioria dos jovens consegue fazer alguma reserva da sua renda mensal, porém metade deles não investe esse valor, mantendo assim o dinheiro na caderneta de poupança e não fazendo o planejamento financeiro adequado para atingirem os seus objetivos.

Este estudo mostrou que a aposentadoria continua sendo um tema de pouca atenção entre os jovens, a grande maioria deles não se preocupa com o tema ou já pensou sobre isso, porém não tomou nenhuma atitude para investir. Tal fato demonstra o risco dos jovens chegarem a terceira idade ainda despreparados, como aconteceu com grande parte das gerações anteriores. Dos que investem nesse propósito, os veículos financeiros mais comuns são previdência privada, poupança, fundos de investimento e títulos públicos.

É de se preocupar que a poupança continua sendo um veículo de maior aplicação entre os jovens, esse fato mostra que existe uma defasagem no 
conhecimento mais específico sobre os tipos de investimentos. Além disso, por estarem em um estágio de vida ainda inicial, Peretti (2008) e Frankenberg (1999) sugerem que os jovens tomem uma postura mais agressiva e busquem outros produtos financeiros com mais retorno, pois em caso de perda, ainda existe tempo para acumulação de patrimônio.

Os resultados dessa pesquisa exploratória mostram a importância de focar na educação financeira dos jovens, pois os mesmos são o futuro da economia do Brasil. Caso nada seja mudado, corremos o risco de mantermos a estatística do INSS (2015) que diz que 99\% dos aposentados do Brasil não atingem a sua liberdade financeira. Vale lembrar também que grandes mudanças relacionadas a previdência social estão sendo elaboradas pelo governo e se os jovens não tomarem o controle das suas finanças, sofrerão as consequências de um futuro cada vez mais difícil de se aposentarem com tranquilidade. Além disso, o estudo em questão serve como uma largada para futuras pesquisas mais aprofundadas sobre esse tema, para acharem soluções que melhorem o déficit da educação financeira do país.

Essa pesquisa exploratória contribui não só para o governo, como também para iniciativas públicas e privadas com o foco nesse tema para poderem desenvolver melhor o seu plano de ação e assim educar financeiramente um maior percentual da população. Adicionalmente, ela contribuiu para as universidades desenvolverem programas e aulas para ensinarem seus alunos a investirem e gerirem seu dinheiro adequadamente, visto que alunos de cursos que já ensinam sobre finanças como administração, ainda possuem um déficit consideravelmente alto sobre o tema. 


\section{Referências Bibliográficas}

ANDERLONI, L.; VANDONE, D. Risk of overindebtedeness and behavioral factors. In: Social Science ResearchNetwork, 2010. Disponível em: <http://papers.ssrn.com/sol3/results.cfm?npage=2\&>. Acesso em: 25 jun. 2017.

ATKINSON, A.; MESSY, F. (2012). Measuring financial literacy: results of the OECD / International Network on Financial Education (INFE) Pilot Study [Working Paper n. 15]. OECD Publishing, Paris. Disponível em: < http://dx.doi.org/10.1787/5k9csfs90fr4-en> Acesso em: outubro, 2017.

BODIE, Zvi; KANE, Alex; MARCUS, Alan J. Fundamentos de investimentos. 3. ed. Porto Alegre: Bookman, 2000

BRASIL, Agência. Mais de $60 \%$ dos brasileiros não faz reserva para a aposentadoria. Disponível em: <http://odia.ig.com.br/economia/2016-0705/mais-de-50-dos-brasileiros-nao-fazem-reserva-para-aposentadoria.html>.

Acesso em: 18 out. 2017

CENTRAL, Banco . O Programa de Educação Financeira do Banco Central.

Disponível

em: <https://www.bcb.gov.br/pre/bcuniversidade/introducaoPEF.asp>. Acesso em: 25 jun. 2017.

CETIP S. A., Unidade de títulos e valores mobiliários: Renda Fixa, 2015. Disponível em: . Acesso em: 01 out.. 2017

CHEROBIM, Ana Paula Mussi Szabo. O que são finanças pessoais. In: CHEROBIM, Ana Paula Mussi Szabo; ESPEJO, Márcia Maria dos Santos Bortolocci (Orgs.). Finanças pessoais: conhecer para enriquecer!. São Paulo: Atlas, 2010a.

COMISSÃO DE VALORES MOBILIARIOS. Mercado de valores mobiliários brasileiro. 1 ed. Rio de Janeiro, 2013. E-book. Disponível em: . Acesso em: 01 out. 2017

DIETRICH, Jônatas ; BRAIDO, Gabriel Machado. Planejamento Financeiro Pessoal para Aposentadoria: Um Estudo com Alunos dos Cursos de Especialização de uma Instituição de Ensino Superior. 2016. 52 p. Artigo Acadêmico (Formando de administração)- UNIVATES, Rio Grande do Sul, 2016. Disponível em: <http://file:///C:/Users/Daniel/Downloads/Dietrich_Braido_2016_PlanejamentoFinanceiro-Pessoa_42378.pdf>. Acesso em: 01 out. $201 \overline{7}$. 
ECONÔMICO, Brasil. Poupança é o investimento preferido do brasileiro, aponta pesquisa da SPC Brasil . Disponível em: <http://economia.ig.com.br/2017-01-30/investimentos-entre-brasileiros.html>. Acesso em: 25 jun. 2017.

ECONÔMICO, Brasil. Aposentadoria: quatro em cada dez jovens deixa de se preparar para o futuro . Disponível em: <http://economia.ig.com.br/201702-02/aposentadoria.html>. Acesso em: 01 out. 2017.

ENEF, Plano Diretor. Educação Financeira. Disponível em: <http://file://C:/Users/Daniel/Desktop/Comportamento\%20do\%20consumidor/Pla no-Diretor-ENEF-Estrategia-Nacional-de-Educacao-Financeira.pdf>. Acesso em: 01 out. 2017.

EXAME, Revista. Aposentadoria é negligenciada por maioria dos brasileiros.

Disponível em: <https://exame.abril.com.br/negocios/dino/aposentadoria-e-negligenciada-pormaioria-dos-brasileiros-dino890103791131/>. Acesso em: 01 out. 2017.

FORTUNA, Eduardo. Mercado Financeiro, Produtos e serviços. 15. ed. Rio de Janeiro: Qualitymark, 2002.

FRANKENBERG, Louis. Seu futuro financeiro, você é o maior responsável: como planejar suas finanças pessoais para toda a vida. 7. ed. Rio de Janeiro: Campus, 2000.

GIARETA, Marisa. Planejamento Financeiro Pessoal: Uma proposta de controle de fluxo de caixa para orçamento familiar. 2011. 38 p. Trabalho de conclusão de curso (Pós graduação em administração)- Universidade Federal do Rio Grande do Sul, [S.I.], 2011.

GITMAN, Lawrence J; JOEHNK, Michel D. Princípios de investimentos. Tradução de Maria Lucia Leite Rosa. 8. ed. São Paulo: Pearson Addison Wesley, 2005.

HALFELD, Mauro. Investimentos: como administrar melhor seu dinheiro. 3. ed. atual. São Paulo: Fundamento, 2007.

Hung, A. A., Parker, A. M., \& Yoong, J. (2009). Defining and measuring financial literacy [Working Paper № 708]. Social Science Research Network, Santa Monica, CA: RAND Corporation. Acesso em: 01 out. 2017, em: $<$ http://papers.ssrn.com/sol3/papers.cfm?abstract id=1498674>

Hung, Angela and Parker, Andrew M. and Yoong, Joanne, Defining and Measuring Financial Literacy (September 2, 2009). RAND Working Paper Series WR-708.

Available at 
SSRN: https://ssrn.com/abstract=1498674 or http://dx.doi.org/10.2139/ssrn.1498

674. Acesso em: 29 set. 2017.

JABUR, Gabriel. Entenda as principais mudanças na reforma da Previdência. Disponível em: <http://www.brasil.gov.br/economia-eemprego/2017/04/entenda-as-principais-mudancas-na-reforma-da-previdencia>. Acesso em: 25 jun. 2017.

KIYOSAKI, Robert; LECHTER, Sharon L. Guia de Investimentos: Aprenda a ganhar dinheiro investindo como os ricos. 20. ed. [S.I.]: Campus, 2002. $416 \mathrm{p}$.

KIYOSAKI, Robert; LECHTER, Sharon L. Pai Rico Pai Pobre: O que os ricos ensinam a seus filhos sobre dinheiro. 2. ed. [S.I.]: Alta Books, 2017. 321 p.

KLAPPER, L.; LUSARDI, A.; PANOS, G. A. Financial literacy and its consequences: Evidence from Russia during the financial crisis. Journal of Banking \& Finance, v. 37, p. 3904-3923, 2013.

LIMA E SILVA, Marineuza Barbosa . Planejamento e Controle Financeiro Pessoal. [S.I.]: Sebrae, 2013. 23 p. Disponível em: <http://www.bibliotecas.sebrae.com.br/chronus/ARQUIVOS_CHRONUS/bds/bds. nsf/3c27b46226d68958621f1f121cdf8f22/\$File/4577.pdf>. Acesso em: 01 out. 2017.

LUCCI, Cintia; ZERRENNER, Sabrina; VERRONE, Marco; SANTOS Sérgio et al. A INFLUÊNCIA DA EDUCAÇÃO FINANCEIRA NAS DECISÕES DE CONSUMO E INVESTIMENTO DOS INDIVÍDUOS . [2006]. 12 p. Trabalho de conclusão de curso (Ciências Contábeis)- FEA, São Paulo, [2006]. Disponível em:

$<$ http://sistema.semead.com.br/9semead/resultado_semead/trabalhosPDF/266.p df>. Acesso em: 25 out. 2017.

MORAES, Fabio; CASTRO, Paulo; MORAIS, Silvia . Mapa da Educação Financeira no Brasil: Uma análise das iniciativas existentes e as oportunidades para disseminar o tema em todo o País. [S.I.: s.n.], 2013. 4 p. Disponível em: <http://www.vidaedinheiro.gov.br/docs/RelatorioAnaliticoENEF.pdf >. Acesso em: 25 jun. 2017.

O planejamento financeiro pessoal e familiar. In: CHEROBIM, Ana Paula Mussi Szabo; ESPEJO, Márcia Maria dos Santos Bortolocci (Orgs.). Finanças pessoais: conhecer para enriquecer! São Paulo: Atlas, 2010b.

O'NEILL, B.; XIAO, J. Financial Behaviors Before and After the Financial Crisis: Evidence from an Online Survey.Journal of Financial 
Counseling and Planning,v. 23, n. 1, p. 33-46, 2012.

ORGANISATION FOR ECONOMIC CO-OPERATION AND DEVELOPMENT (OECD, 2012). High-Level Principles on National Strategies for Financial Education, OECD Publishing. 2012. Disponível em: $<$ http://www.oecd.org/finance/financial-

education/OECD_INFE_High_Level_Principles_National_Strategies_Financial_E ducation_APEC.pdf>. Acesso em: 25 jun. 2017.

ORGANISATION FOR ECONOMIC CO-OPERATION AND DEVELOPMENT (OECD, 2013). Financial literacy and inclusion: Results of OECD/INFE survey across countries and by gender. OECD Publishing. 2013. Disponível em: <http://www.oecd.org/daf/fin/financialeducation/TrustFund2013_OECD_INFE_Fin _Lit_and_Incl_SurveyResults_by_Country_and_Gender.pdf >. Acesso em: 25 jun. 2017.

POTRICH, Ani Caroline. VOCÊ É ALFABETIZADO FINANCEIRAMENTE? DESCUBRA NO TERMÔMETRO DE ALFABETIZAÇÃO FINANCEIRA. 2016. 24 p. Acadêmico (Administração)- Universidade do Vale do Rio dos Sinos , [S.I.], 2016. Disponível em: <http://cef.fgv.br/sites/cef.fgv.br/files/[Mendes\%20et\%20al]\%20VOCE\%20E\%20 ALFABETIZADO\%20FINANCEIRAMENTE.pdf>. Acesso em: 25 jun. 2017.

REMUND, D. L. Financial literacy explicated: the case for a clearer definition in an increasingly complex economy.The Journal of Consumer Affairs, v. 44, n. 2, p. 276-295, 2010.

RIBEIRO, Ana Paula. Quando se trata de educação financeira, Brasil fica mal na foto. Disponível em: <https://oglobo.globo.com/economia/negocios/quando-se-trata-de-educacaofinanceira-brasil-fica-mal-na-foto-20385966>. Acesso em: 25 jun. 2017.

ROBB, C. A.; BABIARZ, P.; WOODYARD, A. The demand for financial professionals' advice: The role of financial knowledge, satisfaction, and confidence. Financial Services Review, v. 21, n. 4, 2012.

ROBB, C. A.; SHARPE, D. L. Effect of personal financial knowledge on college students' credit card behavior.Journal of Financial Counseling and Planning, v. 20, p. 25-43, 2009.

ROSS, Stephen A.; WESTERFIELD, Randolph W.; JORDAN, Bradford D. Fundamentos de Administração Financeira. 9. ed. [S.I.]: AMGH, 2013. 767 p. 
SANTOS, Liana Ribeiro dos; KLÖTZE; CABÚS, Marcelo. O conhecimento financeiro e sua relação com a tolerância ao risco e com as decisões de endividamento e investimento. Rio de Janeiro, 2013. 151p. Tese de Doutorado - Departamento de Administração, Pontifícia Universidade Católica do Rio de Janeiro.

SCHMEISER, M. D.; SELIGMAN, J. S. Using the Right Yardstick: Assessing Financial Literacy Measures by Way of Financial Well-Being. The Journal of Consumer Affairs, v. 47, n. 2, p. 243-262, 2013.

SEGUNDO FILHO, José. Finanças pessoais: invista no seu futuro. Rio de Janeiro: Qualitymark, 2003.

SERASA EXPERIAN. Brasileiro aprende sobre Finanças, mas não reflete no Comportamento. 2015. Disponível em: <http://noticias.serasaexperian.com.br/blog/2015/09/08/nivel-de-conhecimentodo-brasileiro-sobre-educacao-financeira-aumenta-mas-ainda-nao-se-reflete-nocomportamento/> Acesso em: maio, 2017.

VIEIRA, Marina de Freitas Alves . Conhecimento de crédito e comportamento do uso do cartão de crédito. 2017. 41 p. Trabalho de conclusão de curso (Formando de administração)- Pontifícia Universidade Católica do Rio de Janeiro, Rio de Janeiro, 2017. Disponível em: $<$ https://mail.google.com/mail/u/0/\#search/liana.ribeiro\%40prof.iag.puc-

rio.br/15de6e4b914eb25b?projector=1>. Acesso em: 01 out. 2017.

YAZBEK, Priscila . Brasil é o 74으 em ranking global de educação financeira. 19/11/2015. Disponível em: <http://exame.abril.com.br/seudinheiro/brasil-e-o-740-em-ranking-global-de-educacao-financeira/>. Acesso em: 25 jun. 2017. 


\section{Anexo 1}

QUESTIONÁRIO EM FINANÇAS PESSOAIS - EDUCAÇÃO FINANCEIRA E INVESTIMENTO

\section{Seção 1 - Sobre Você}

1. Sexo

( ) Masculino ( ) Feminino

2. Qual a sua idade?

3. Qual é seu nível de escolaridade:

( ) Superior completo ( ) Superior Incompleto ( ) Nenhuma das opções acima

Caso o entrevistado marque a terceira opção, encerrar a pesquisa Caso o entrevistado marque superior incompleto, pular para questão 4 Caso o entrevistado marque superior completo, pular para questão 5

4. Qual curso que está fazendo:

5. Qual curso você fez?

6. Qual a sua renda mensal individual?

( ) Até $\mathrm{R} \$ 1.244$

( ) De $R \$ 1.244$ a $R \$ 2.488$

( ) De $R \$ 2.489$ a $R \$ 6.220$

( ) De $R \$ 6.221$ a $R \$ 12.440$

( ) Mais de $\mathrm{R} \$ 12.440$ 


\section{Seção 2 - Educação Financeira}

7. Ao longo de um ano o dinheiro ganho por uma pessoa dobrou e os preços dobraram também. No final desse ano, quanto essa pessoa conseguirá comprar com o esse dinheiro?

( ) Mais que no início do ano

( ) A mesma quantidade

( ) Menos que no início do ano

( ) Não sei

8. Hoje, uma pessoa depositou um dinheiro na poupança. O rendimento da poupança é de $5 \%$ ao ano. A inflação é de $6 \%$ ao ano. Daqui a 1 ano, quanto essa pessoa conseguirá comprar com esse dinheiro da poupança?

( ) Mais que hoje

( ) Exatamente o mesmo

( ) Menos que hoje

( ) Não sei

9. Hoje, uma pessoa depositou $\mathrm{R} \$ 1.000,00$ em um CDB. O rendimento do CDB é de $10 \%$ ao ano. Depois de 5 anos, quanto essa pessoa deverá ter nessa poupança, se ela não fizer novos depósitos, nem saques?

( ) Mais de $R \$ 1.500,00$

( ) Exatamente $R \$ 1.500,00$

( ) Menos de $\mathrm{R} \$ 1.500,00$

( ) Não sei

\section{Seção 3 - Investimentos}

10. Quando uma pessoa divide seu dinheiro entre vários investimentos diferentes,

ela diminui o risco de perder dinheiro.

( ) Verdadeiro

( ) Falso

( ) Não sei

11. Quando uma pessoa compra um CDB (Certificado de Depósito Bancário) de um

banco ela está emprestando dinheiro para o banco.

( ) Verdadeiro

( ) Falso

( ) Não sei 
12. Os títulos públicos federais são investimentos de baixo risco.

( ) Verdadeiro
( ) Falso
( ) Não sei

13. Normalmente, qual ativo apresenta as maiores oscilações ao longo do tempo?

( ) Títulos públicos

( ) Ações

( ) Poupança

( ) Não sei

14. Considerando-se um longo período de tempo (ex.: 10 anos), qual ativo, normalmente, oferece maior retorno?

( ) Títulos públicos

( ) Ações

( ) Poupança

( ) Não sei

\section{Seção 4 - Planejamento Financeiro e Aposentadoria}

15. Como você sente a respeito dos seus conhecimentos para gerenciar seu próprio dinheiro?

( ) Nada seguro - Eu gostaria de possuir um nível muito melhor de educação financeira

( ) Não muito seguro - Eu gostaria de saber um pouco mais sobre finanças

( ) Razoavelmente seguro - Eu conheço a maioria das coisas que eu precisaria saber sobre o assunto

( ) Muito seguro - Eu possuo conhecimentos bastante amplos sobre finanças

16. Nos últimos doze meses, qual destas afirmativas descreve sua atitude de poupança/investimento?

( ) Eu não consigo economizar nada

( ) Em alguns meses, eu consegui economizar um pouco e investir

( ) Na maioria dos meses, eu consegui economizar e investir

( ) Em alguns meses, eu consegui economizar um pouco, mas não investi em nada

( ) Na maioria dos meses, eu consegui economizar, mas não investi em nada 
17. Em relação à sua aposentadoria, qual das alternativas abaixo melhor representa sua situação?

( ) Não me preocupei com isso ainda - Pular para a Q18

( ) Pretendo ter apenas a aposentadoria do governo - Pular para a Q18

( ) Faço um plano de previdência/poupança própria para aposentadoria - Pular para a Q19

( ) Faço investimentos de longo prazo visando a aposentadoria - Pular para a Q19

( ) Tenho planos de começar a poupar para isso - Pular para a Q18

( ) Não vejo necessidade de poupar para minha aposentadoria - Pular para a Q18

18. Quais das opções de investimentos abaixo você já possui? Você pode marcar mais de uma opção.

( ) Poupança

( ) Títulos Públicos

( ) CDB

( ) Letra de Crédito de Agronegócio (LCA) ou Letra de Crédito Imobiliário (LCl)

( ) Fundos de Investimento

( ) Previdência Privada

( ) Ações

( ) Não invisto em nada

\section{Após responder à questão 18, finalizar a pesquisa.}

19. Quais das opções de investimentos você investe com o foco na aposentadoria? Você pode marcar mais de uma opção.

( ) Poupança

( ) Títulos Públicos

( ) CDB

( ) Letra de Crédito de Agronegócio (LCA) ou Letra de Crédito Imobiliário (LCI)

( ) Fundos de Investimento

( ) Previdência Privada

( ) Ações

( ) Não invisto em nada

20. Além dos investimentos com foco na aposentadoria, quais outras opções de investimento você também faz?

( ) Poupança

( ) Títulos Públicos

( ) CDB

( ) Letra de Crédito de Agronegócio (LCA) ou Letra de Crédito Imobiliário (LCI)

( ) Fundos de Investimento

( ) Previdência Privada

( ) Ações

( ) Não invisto em nada 